\title{
Transfer of moisture through the unsaturated zone in the tropical forest using the neutron probe
}

\author{
${ }^{1 * A . ~ T . ~ F o u e ́ p e ́ ; ~}{ }^{2}$ L. Kengni; ${ }^{3}$ V. V. S. Gurunadha Rao; ${ }^{4} J$. R. Ndam \\ Institute for Geological and Mining Research-Hydrological Research Centre, P.O. Box 4110, Yaounde, Cameroon \\ ${ }^{2}$ Department of Earth Sciences, University of Dschang, P.O. Box 67, Dschang, Cameroon \\ ${ }^{3}$ National Geophysical Research Institute, Hyderabad- 500 606, India \\ ${ }^{4}$ Department of Earth Sciences, University of Yaounde I, BP 812, Yaounde, Cameroon
}

\begin{abstract}
Received 4 December 2008; $\quad$ revised 14 April 2009; accepted 10 May 2009
ABSTRACT: Knowledge of moisture content is crucial in assessing spatial and temporal movement of water through the unsaturated zone. Moisture storage is also important for monitoring the soil water balance and for validation of water balance models. The purpose of this work was to determine and analyse moisture content profiles at point locations in the unsaturated zone of a lateritic soil around Nsimi, south of Cameroon. Neutron probe has been connected to a set of tensiometers in an area of 60 ha. A comparative study between a site covered with vegetation and a site uncovered was conducted to assess the influence of vegetation in the process of moisture transfers. The results showed that the spatial distribution of moisture profiles varied according to the site and the texture of the soil, with in general increasing of moisture from the surface horizon toward the deeper layers. The mean values of moisture varied from $\theta_{\mathrm{m}}=$ $0,397 \mathrm{~cm}^{3} / \mathrm{cm}^{3}$ on barren site, against $\theta_{\mathrm{m}}=0,429 \mathrm{~cm}^{3} / \mathrm{cm}^{3}$ in vegetation. Values of suction were generally strong in surface and at depth, but weak in the intermediate layers.
\end{abstract}

Keywords: Barren soil; Calibration; Lateritic soil; Neutron probe; Tensiometer

\section{INTRODUCTION}

The sustainable management of a natural ecosystem requires knowledge of different processes that are involved. The unsaturated zone plays a very important role in infiltration, deep percolation or recharge, water balance and the drainage systems because it is in this interface that exchanges of water, pollutants and microorganisms into the ground water or the atmosphere occur (Braun et al., 1997; 2005; Thais, 2004). The study of soil water must be addressed both in quantity and in terms of energy. Several methods are available for determining the moisture content of the subsurface zone: gravimetric methods, neutron thermalization and time domain reflectometry (Dalton, 1992; Healey and Cook, 2002). Although the first method leads in reshuffle of the soil, it is generally used as a standard for the other ones (Evett, 2004). Since the last few decades, the neutron probe has been widely used in Europe and America for determining the moisture content of the soil (Pourrut and Camus, 1970).

$\triangle$ *Corresponding Author Email: afouepe@yahoo.fr

Tel: +237 9624 0468; Fax: +237 22222431
It is convenient, fast, simple and it enables the instantaneous and continuous moisture measurement on the same point without disturbing the ground. However, this technology is rarely used in Sub Saharan Africa (Olivry and Sircoulon, 1998). Important work on the transfer of water in the unsaturated zone has been conducted in the past on this site using gravimetric methods (Fih, 1999). Disturbance of soil and nonrecurrence of tests are the major disadvantages of this method (Fares et al., 2004). The concern is how to track variation in soil moisture on daily basis while respecting the soil structure. The major difference between this work and those already made at the site include the use of neutron probe that does not require the disturbance of soil and the possibility of continuous determination of moisture in the ground at fixed points. The method uses the real dry bulk density of soil, for determining the volumetric moisture content. The calibration of neutron probe is a very important task of this work. The objective of this study was to determine and analyze the moisture profiles in the unsaturated 


\section{A. T. Fouépé et al.}

zone of the Mengong drainage basin by nondestructive method.

\section{MATERIALS AND METHODS}

Study area

The data collection for this study was performed from June $11^{\text {th }}$ of 2005 to May $8^{\text {th }}$ of 2006 . The Nsimi watershed lies on the southern Cameroon plateau and is situated at about $120 \mathrm{~km}$ to the South of Yaounde, near the Nsimi village in the tropical rain forest (latitude $3^{\circ} 10^{\prime} \mathrm{N}$, longitude $11^{\circ} 51^{\prime} \mathrm{E}$ ) covering an area of 60 ha (Fig. 1). It is made up of two convexo-concave sloped hills with average elevation of $700 \mathrm{~m}$ (amsl), both of which are separated by a marshy valley through which the Mengong brook passes with a mean annual discharge of $51 / \mathrm{s}$ (Viers et al., 1997). The annual rainfall varies between 1600 and $2000 \mathrm{~mm}$ with an annual average temperature of about $27^{\circ} \mathrm{C}$. The climate is of the Guinean type. Most of the catchment area is covered by a thick shrub. The vegetation appears locally deteriorated because of clearing forest for food crops. The vegetation is made of grass and trees that are always green. These sites have been chosen to highlight the influence of vegetation cover on the kinetics of moisture transfer between different horizons. The swampy depression is the domain of semi-aquatic plants like raffia or palm trees (Boeglin et al., 2003). The weathering mantle of this area (Fig. 2) is made up of very thick lateritic cover formed on hypersthene granites (charnokites) of Liberian age (2800 MA) belonging to the northern part of the Congo craton (Braun et al., 1998; Lasserre and Soba, 1979; Toteu et al., 2001). This weathered cover is differentiated into three main groups of horizons represented from bottom to top by very thick limono-sandy saprolite comprising the nodular horizon made up of ferruginous nodules with a dominantly clayey matrix, a superficial loose horizon rich in clay, overlain by a very thin humiferous layer. The bulk dry density of the soil at mid-slope where the study was carried out is $1.06 \mathrm{~g} / \mathrm{cm}^{3}$ for the surface layers $(0-20 \mathrm{~cm})$ and $1.27 \mathrm{~g} / \mathrm{cm}^{3}$ for deep layers (below $20 \mathrm{~cm}$ ). This weathered cover is differentiated into three main groups of horizons represented from bottom to top by very thick limono-sandy saprolite comprising the nodular horizon made up of ferruginous nodules with a dominantly clayey matrix; a superficial loose horizon rich in clay, overlain by a very thin humiferous layer. The bulk dry density of the soil at mid-slope where the study is carried out is $1.06 \mathrm{~g} / \mathrm{cm}^{3}$ for the surface layers $(0-20 \mathrm{~cm})$ and $1.27 \mathrm{~g} / \mathrm{cm}^{3}$ for deep layers (below $20 \mathrm{~cm}$ ). The hydraulic conductivity in the basin varying from $3.7 \mathrm{e}^{-04} \mathrm{~m} / \mathrm{s}$ on the higher hillside to $1.5 \mathrm{e}^{-06} \mathrm{~m} / \mathrm{s}$ on the lower hillside (Sekhar et al., 2007).

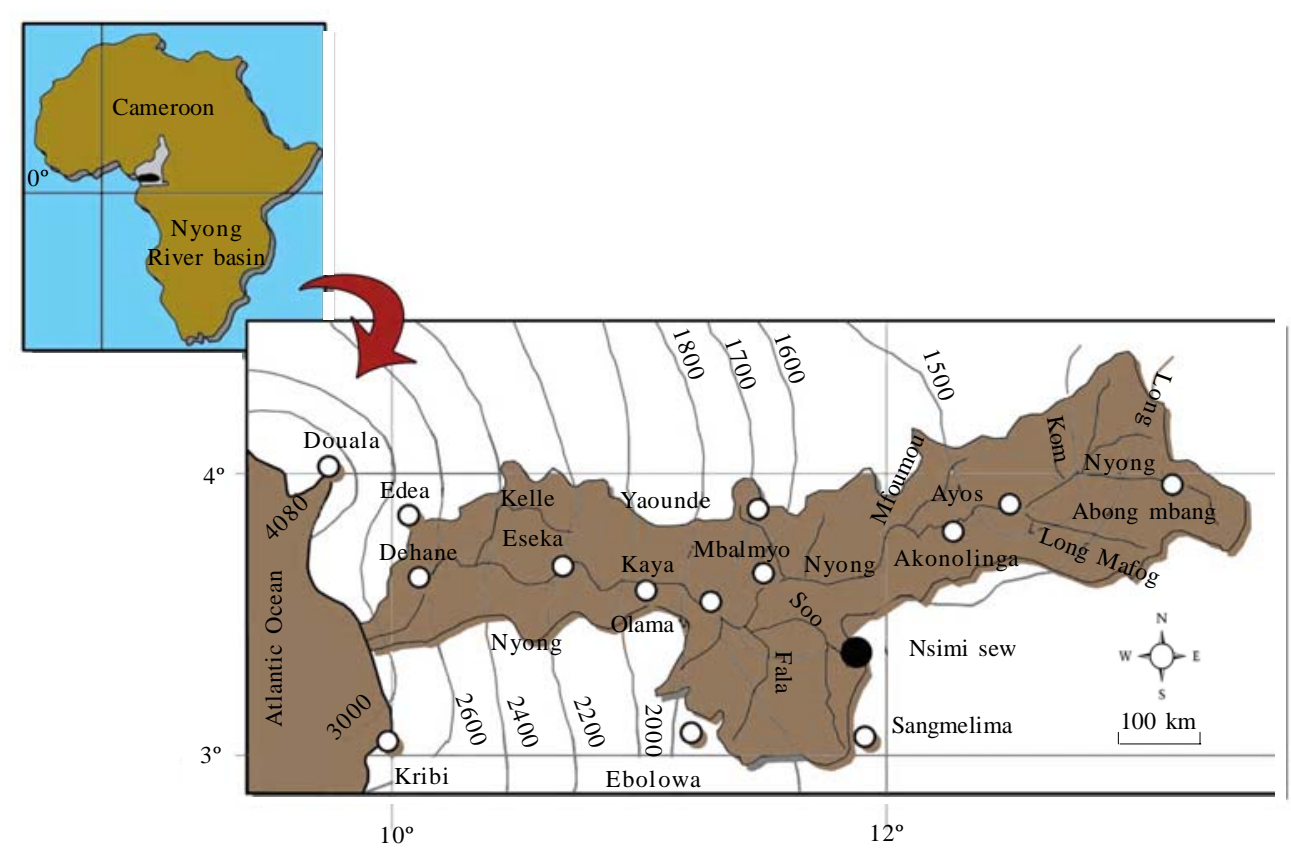

Fig. 1: Location of the Nsimi experimental watershed (SEW) in the Nyong drainage basin 
Int. J. Environ. Sci. Tech., 6 (3), 379-388, Summer 2009

\begin{tabular}{|c|c|c|c|c|c|c|}
\hline Depth & Lateritic soil section & Horizons & $\begin{array}{c}\text { Clay } \\
(\%)\end{array}$ & $\begin{array}{l}\text { Silt } \\
(\%)\end{array}$ & $\begin{array}{r}\text { Sand } \\
(\%)\end{array}$ & $\begin{array}{c}\text { Stone } \\
(\%)\end{array}$ \\
\hline $0 \mathrm{~m}$ & & Humeferous layer & 46.95 & 2.05 & 95 & 0 \\
\hline & & Loose clay-rich & 64.22 & 8.21 & 27.52 & 0 \\
\hline \multicolumn{7}{|l|}{$5 \mathrm{~m}$} \\
\hline \multirow[t]{2}{*}{$10 \mathrm{~m}$} & & Indurated ferruginous clay & 21.81 & 3.41 & 14.11 & 60.67 \\
\hline & & Saprolite & 24.09 & 30.71 & 40.80 & 4.4 \\
\hline \multirow[t]{2}{*}{$35 \mathrm{~m}$} & & & & & & \\
\hline & & Granitic bedrock & - & - & - & - \\
\hline
\end{tabular}

Fig. 2: A simplified lateritic soil section of the Nsimi watershed developed on a granitic bedrock. This vertical section shows different pedological horizons and their principal granulometric classes (Yene Atangana et al., 2003)

\section{Gravimetric method}

When laying access tubes for neutron moisture probe depth, soil sample were taken at intervals of 10 $\mathrm{cm}$. The collected samples were packed with aluminum foil and then weighed $\left(h_{w}\right)$. They were then dried at $105^{\circ} \mathrm{C}$ in an oven for $48 \mathrm{~h}$ and weighed again $\left(\mathrm{d}_{\mathrm{w}}\right)$. The weighted moisture content is given by the following equation:

$w=\frac{h_{w}-d_{w}}{d_{w}}$

and the volumetric moisture was obtained from this equation:

$\theta_{v}=d a . w$

Where, $\theta_{\mathrm{v}}$ : volumetric moisture content $\left(\mathrm{cm}^{3} / \mathrm{cm}^{3}\right)$; $\mathrm{W}$ : weighted moisture (g/g); Da: bulk dry density of the soil.

\section{Neutron moisture probe}

A neutron moisture measuring probe using a sealed mixture source of radioactive americium 241 and beryllium with an activity ranging from 0.4 to 1.9 gigabequerels was used to measure the soil moisture content. Two hard aluminum tubes of $2 \mathrm{~m}$ each were implanted at two locations: one on barren area (B.S.) and another on vegetated area (V.S.). Measurements were made sequentially, leaving the probe at a depths $\mathrm{Z}$ (respectively at $15,25,35,45,55,65,75,85,95,105$, $115,125,135,145,155,165,175,185$ and $200 \mathrm{~cm}$ ) for a period $\Delta t=65 \mathrm{~s}$ and registering the number of counts $\mathrm{N}$. The probe was then lowered with an incremental of $\Delta \mathrm{z}=10 \mathrm{~cm}$ and the same operations were repeated up to the base of the tube. In addition, to take account of the possible neutron drift, relative count values $(\beta)$ were obtained from the equation:

$\beta=N / E$,

Where, $\mathrm{E}$ is the counting in the water in a container. Four measurements were performed per week. The calibration of the neutron probe was made by comparing the gravimetric measurements made during implementation of the access tubes and neutron counts measured by the probe (Reichardt et al., 1997). For every layer, a calibration curve was prepared using:

$\theta_{v}=a \cdot \beta+b$

Where, a and b refer respectively to the slope and the intercept of the regression line obtained while plotting $\theta_{\mathrm{v}}=\mathrm{f}(\mathrm{N})$ and $\theta_{\mathrm{v}}$ is the volumetric moisture (Evett, 2003).

By integrating the calibration equations following the depth, one gets the amount of water stored on the site at each measurement. The extrapolation of these 
data to the entire basin gives a value of the volumetric moisture content in the basin at the time. It is also possible to determine the amount of moisture stored or retrieved on a site between two dates, by differentiation of results.

\section{Tensiometers}

One can also characterize in another way the soil moisture by measuring the force that binds water to the rock or soil, what is known as capillary potential. The hydraulic tension or suction $\psi$ measures the energy state and reflects the degree of saturation of soil. It is low in saturated soils condition and enhanced in dry soils. This positive suction value has been used to develop curves and profiles. At the experimental site in the Nsimi Basin, Multi-system tensiometric measurements were made using (STM 2150) tubes. Each site was equipped with a battery of tensiometers exploring various depths $(10,30,50,70,100,120,140$, 180, 200 and $220 \mathrm{~cm}$ ). The hydraulic potential H, which is the height at which water could rise in a piezometer was obtained by:

\section{$H=-12.6 L+Y$}

Where, $\mathrm{L}$ is the rise of mercury in the tube and $\mathrm{Y}$ is the distance between the level of mercury in the tube and the surface. Tensiometric measurements were carried out along with the neutron counting. The rainfall data were obtained from rain gauge installed on the area.

\section{Data analysis}

The critical examination of data was allowed to systematically eliminate some visual aberrations. All regression equations and statistical analysis were performed using statistical software SPSS 10.0.

\section{RESULTS AND DISCUSSION}

Calibrating the neutron probe and moisture profiles

The review of the top soil explored by the neutron moisture probe revealed that there are two distinct layers (Fig. 2): the first from $0-70 \mathrm{~cm}$ and the second from 70-200 $\mathrm{cm}$. However, neutron losses in the atmosphere near the surface necessitated a separate calibration for the portion up to $20 \mathrm{~cm}$ (Evett and Steiner, 1995; Falleiros et al., 1993). Three straight calibration curves corresponding to respective soil layers were determined for each site (Table 1). Statistical analysis of experimental data showed acceptable correlations $(p=0.01)$ and indices of reliability of more than 0.67 (Table 2). The regression equations tended to have coefficients of determination $\mathrm{R}^{2}$ as $0.62 \leqslant \mathrm{R}^{2} \leqslant 0.85$. These equations were used for the transformation of neutron counts into volumetric moisture content. The observation of established profiles (Fig. 3) indicated that the neutronic method was slightly maximizing the moisture values at $110-140 \mathrm{~cm}$ depth. The results indicated that the moisture content varied in space and time with slight increases from the surface to depths. This same trend were obtained by Reedy and Scalon (2003) who used the electromagnetic induction to predict average water content of the soil profile at point locations in Texas, USA and by Vicente et al. (2003) during the comparison of soil water-contents measured with a neutron probe and time domain reflectometry in a Mediterranean forest of Central Western Spain. The measured average moisture content varied from $\theta_{\mathrm{m}}=0,429 \mathrm{~cm}^{3} / \mathrm{cm}^{3}$ for vegetative area to $\theta_{\mathrm{m}}=0,397$ $\mathrm{cm}^{3} / \mathrm{cm}^{3}$ for barren site. This trend was also observed by Fih (1999) on the same site by the gravimetric method during the period from October 1998 to February 1999; He noted that the average moisture content varied from $\theta_{\mathrm{m}}=0,339 \mathrm{~cm}^{3} / \mathrm{cm}^{3}$ for vegetative area and $\theta_{\mathrm{m}}=0,302 \mathrm{~cm}^{3} /$ $\mathrm{cm}^{3}$ on barren land. The difference could be attributed to the fact that the previous study was carried out in the rainy season while this study was carried out during dry season. At a given date, moisture content varied with depth; the maximum being in the middle layer (Table 3a and 3b). This can be explained by changes in hydrodynamic properties and grain size of the soil with depth. Indeed the saturated hydraulic conductivity (Ks) decreased rapidly from the surface to $30 \mathrm{~cm}$ depth (Fig. 4) (Kuitcha, 2002; Tienjo, 2007). It should be recall that the DOC concentrations measured in the soil by Braun et al. (2005) have been found also to be decreasing with depth. This can show the link between moisture and chemical transfer (Ndam, 1997). Moisture profiles variation with time generally followed the rainfall activity i.e after a rainy episode there was an increasing rate of moisture content. However, since the study period coincided with the transition wet-dry season, profiles trended to move from right to left (Fig. 5). The spatial distribution of profiles was different from one site to another. At vegetated area, there was a spread of the distribution of the profiles, whereas the phenomenon was slightly different on uncovered site. These results generally corroborated those obtained by Fih (1999). 
Int. J. Environ. Sci. Tech., 6 (3), 379-388, Summer 2009

Table 1: Calibration equations for the vegetated site (VS) and the barren site (BS)

\begin{tabular}{|c|c|c|c|c|}
\hline Sites & Depths & Equations & $\mathrm{R}^{2}$ & $\mathrm{~N}$ \\
\hline \multirow{2}{*}{ Barren } & $0-20 \mathrm{~cm}$ & $\theta_{\mathrm{v}}=0.3583 \beta+0.2172$ & 0.62 & 6 \\
\hline & $20-70 \mathrm{~cm}$ & $\theta_{\mathrm{v}}=0.8716 \beta-0.0409$ & 0.61 & 15 \\
\hline \multirow{4}{*}{ Vegetated } & $70-170 \mathrm{~cm}$ & $\theta_{\mathrm{v}}=0.9528 \beta-0.0775$ & 0.61 & 22 \\
\hline & $0-20 \mathrm{~cm}$ & $\theta_{\mathrm{v}}=0.2919 \beta+0.2457$ & 0.62 & 6 \\
\hline & $20-70 \mathrm{~cm}$ & $\theta_{\mathrm{v}}=2.0243 \beta-0.6334$ & 0.70 & 12 \\
\hline & $70-150 \mathrm{~cm}$ & $\theta_{\mathrm{v}}=1.397 \beta-0.3217$ & 0.64 & 25 \\
\hline
\end{tabular}

$\mathrm{R}^{2}$ : coefficients of determination; $\mathrm{N}$ : number of sample

Table 2: Statistical data for the calibration

\begin{tabular}{lccc}
\hline Sites & correlation coefficient of Pearson & level of significance $(\mathrm{p})$ & Index of reliability $(\alpha)$ \\
\hline Barren & 0.72 & 0.01 & 0.67 \\
Vegetated & 0.93 & 0.01 & 0.95 \\
\hline
\end{tabular}

Table 3: Mean volumetric moisture content (a and b)

\begin{tabular}{|c|c|c|c|c|c|}
\hline \multicolumn{3}{|c|}{ (a) } & \multicolumn{3}{|c|}{ (b) } \\
\hline Depths (cm) & \multicolumn{2}{|c|}{ Sites } & Depths $(\mathrm{cm})$ & \multicolumn{2}{|c|}{ Sites } \\
\hline & B.S. $\left(\mathrm{cm}^{3} / \mathrm{cm}^{3}\right)$ & V.S. $\left(\mathrm{cm}^{3} / \mathrm{cm}^{3}\right)$ & & B.S. $\left(\mathrm{cm}^{3} / \mathrm{cm}^{3}\right)$ & V.S. $\left(\mathrm{cm}^{3} / \mathrm{cm}^{3}\right)$ \\
\hline $0-20$ & 0,383 & 0,378 & $0-20$ & 0,268 & 0.308 \\
\hline $20-70$ & 0,462 & 0,428 & $20-70$ & 0,322 & 0.346 \\
\hline $70-150$ & 0,443 & 0,386 & $70-150$ & 0,313 & 0.364 \\
\hline
\end{tabular}

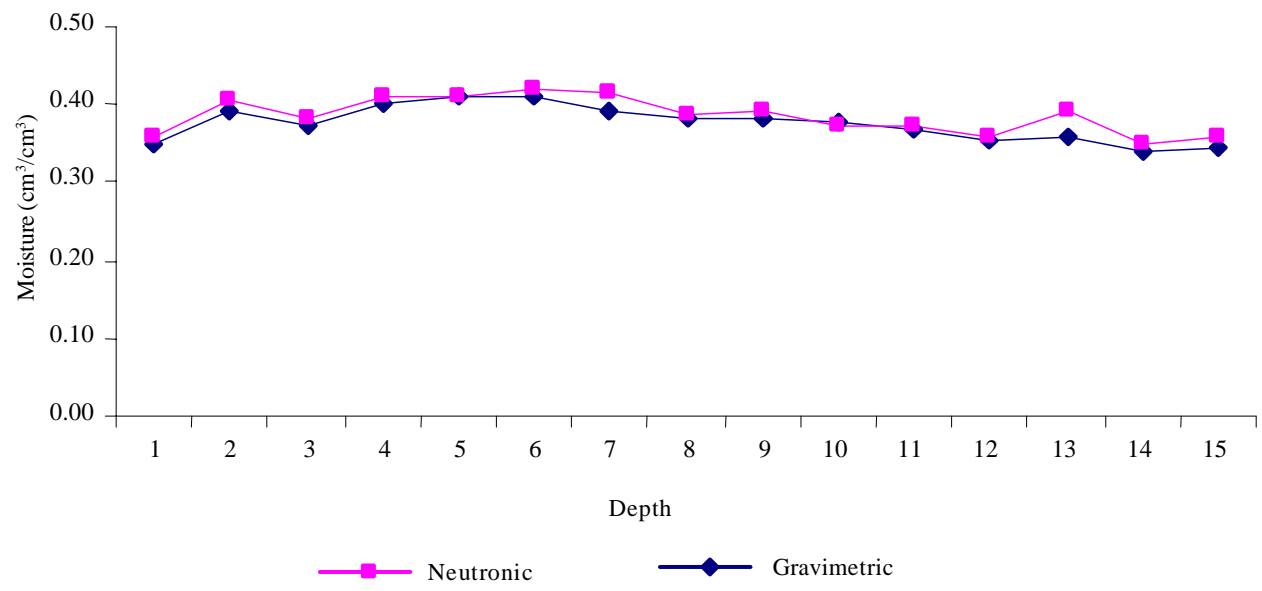

Fig. 3: Comparison between neutronic and gravimetric profiles. These profiles show that there is a good correlation between neutron probe and gravimetric moisture measurements

\section{Moisture storage in soil profile}

By integrating equations in Table 1 , one thus obtains from Table 3a, approximately $361 \mathrm{~cm}^{3}$ per surface unit of moisture storage under vegetated site against 323 $\mathrm{cm}^{3}$ per surface unit on the barren site. Apart from the influence of vegetation, this may be explained by the fact that the vegetated site has an average clay horizon thickness of $230 \mathrm{~cm}$ followed by a nodular horizon, compared to $180 \mathrm{~cm}$ for the barren site; but it was demonstrated at the site of Nsimi that clay horizon has a higher capacity of holding water with lower hydraulic conductivities under natural conditions than nodular horizon (Fih, 1999; Kuitcha, 2002; Tienjo, 2007). The results indicate that the moisture storage in vegetative area will be more than in barren site as vegetation provides good infiltration of water through roots (Norman and Gary, 1990). Expanding the investigation 
A. T. Fouépé et al.

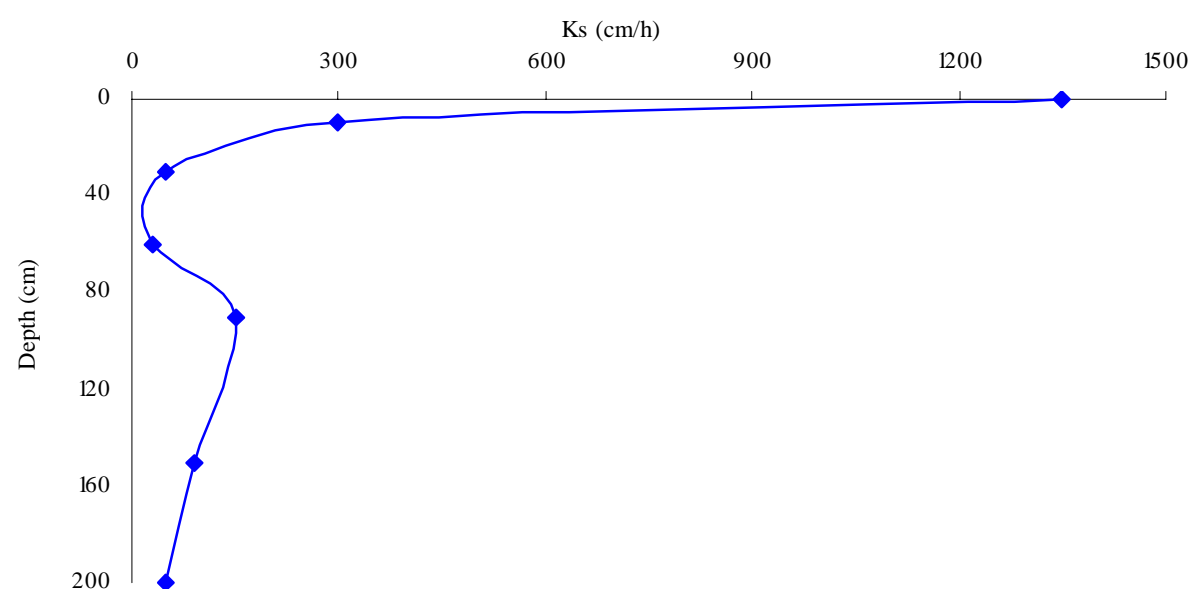

Fig. 4: Variation of the coefficient of permeability at saturation with depth. One can notice the important decrease of the permeability from the surface to $40 \mathrm{~cm}$ depth (Tienjo, 2007)
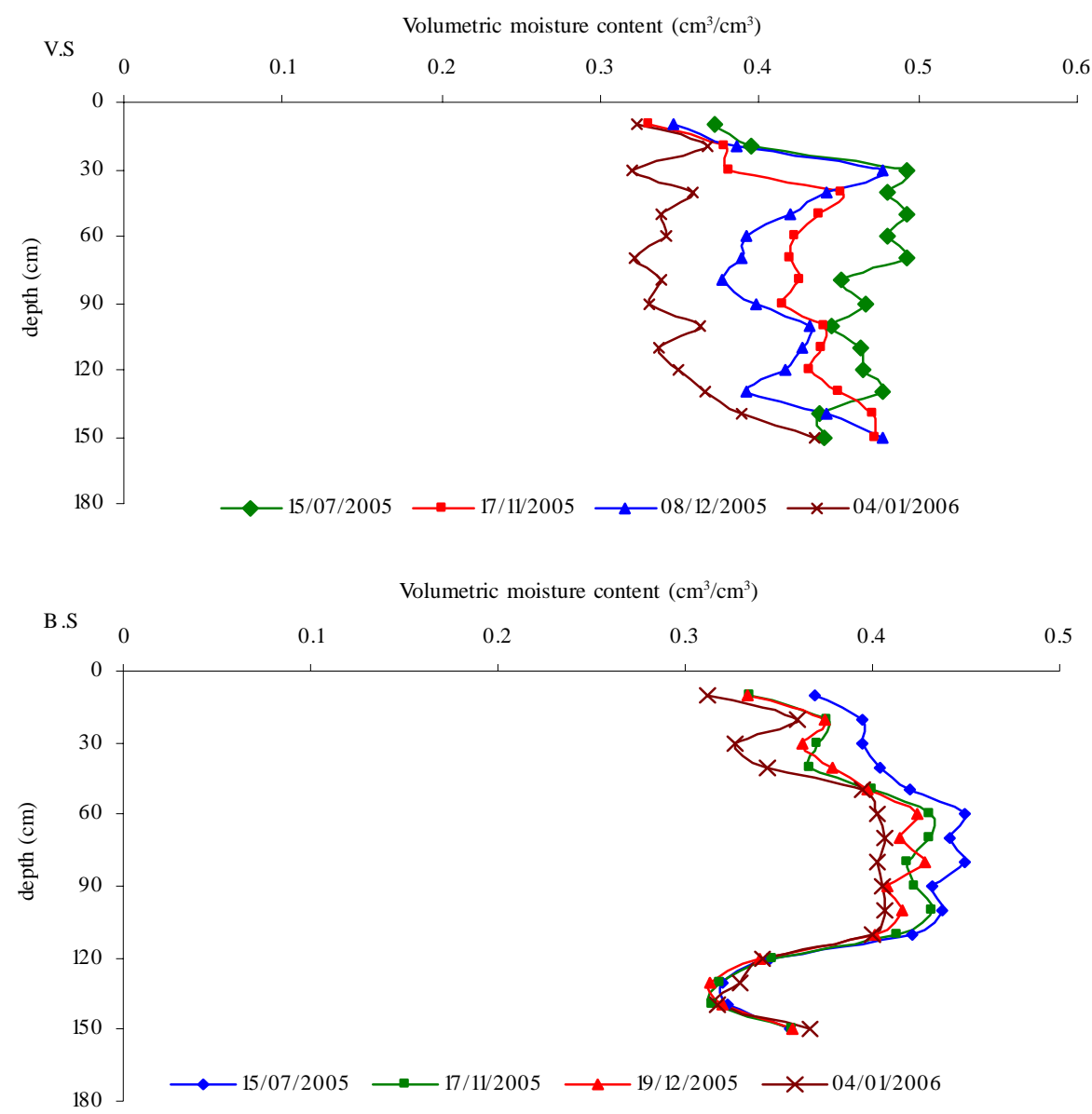

Fig. 5: Soil moisture profiles (V.S and B.S). These profiles show the influence of the vegetation on the aerial distribution of soil moisture content 
depth of the neutron probe could allow the possibility of measuring ground water recharge at depth where ground water is present. For this purpose, Maréchal et al. (2008) suggested an integrated approach coupling hydrogeological to geochemical monitoring.

\section{Kinetics of moisture movement}

The measurement carried out during October 2 and 9, 2005 had provided information for evaluating the behaviour of soil moisture profiles following the precipitation events. Between these two dates, 46.5 $\mathrm{mm}$ of rainfall had been recorded. It was observed that there was a superposition of the two profiles on barren site, for the 0-40 cm depths and beyond $110 \mathrm{~cm}$ and an enhancement (5\%) in moisture in the $40-110 \mathrm{~cm}$ zone after the precipitation. As the runoff was negligible and evapotranspiration limited, the increase in moisture content at depth $40 \mathrm{~cm}$ was probably due to infiltration
(Fig. 6). A similar increase in moisture content was also observed on the vegetated site. In addition, it was observed that the moisture front (moving at variable speed of 5 to $26 \mathrm{~cm} / \mathrm{d}$ ), had moved deep into the soil on barren land. The presence of vegetation showed a significant influence on soil moisture content, as well as moisture movement. The variable residence time of water within the soil, creating an alternation of reducing and oxidizing conditions, affects soil chemistry, structure and lateral extension of the soil patterns (Temgoua et al., 2005).

\section{Tensiometric measurements}

Tensiometric profiles showed a marked and more individualized behaviour at the vegetated site (Fig. 7). The profiles showed a continuous draining of moisture within the soil. The barren site showed a linear progression, with higher moisture content at the
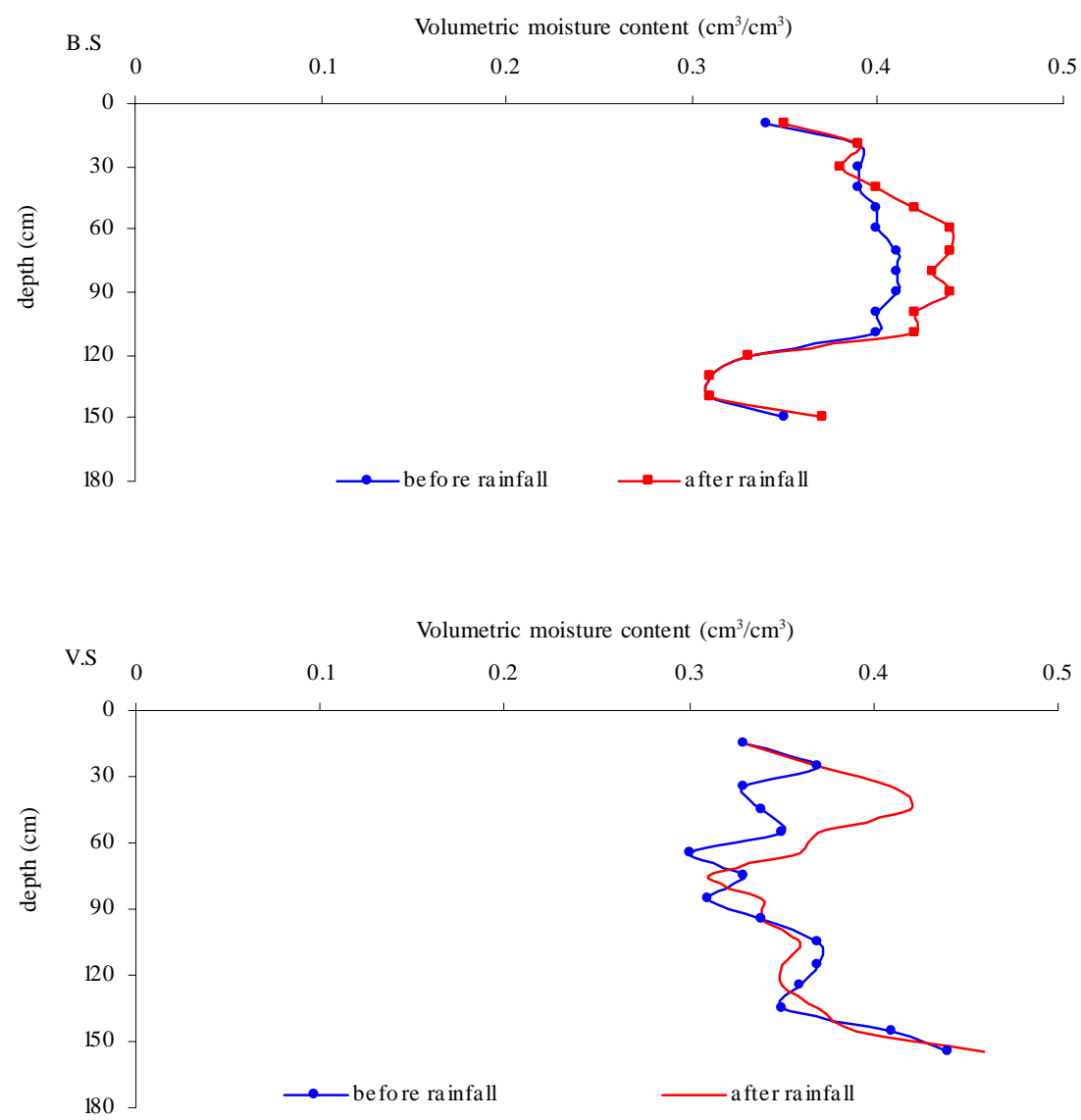

Fig. 6: Moisture profiles before and after rainfall (V.S and B.S). These profiles illustrate that enhance in soil moisture content after precipitation is greater in vegetated area compare to barren area 

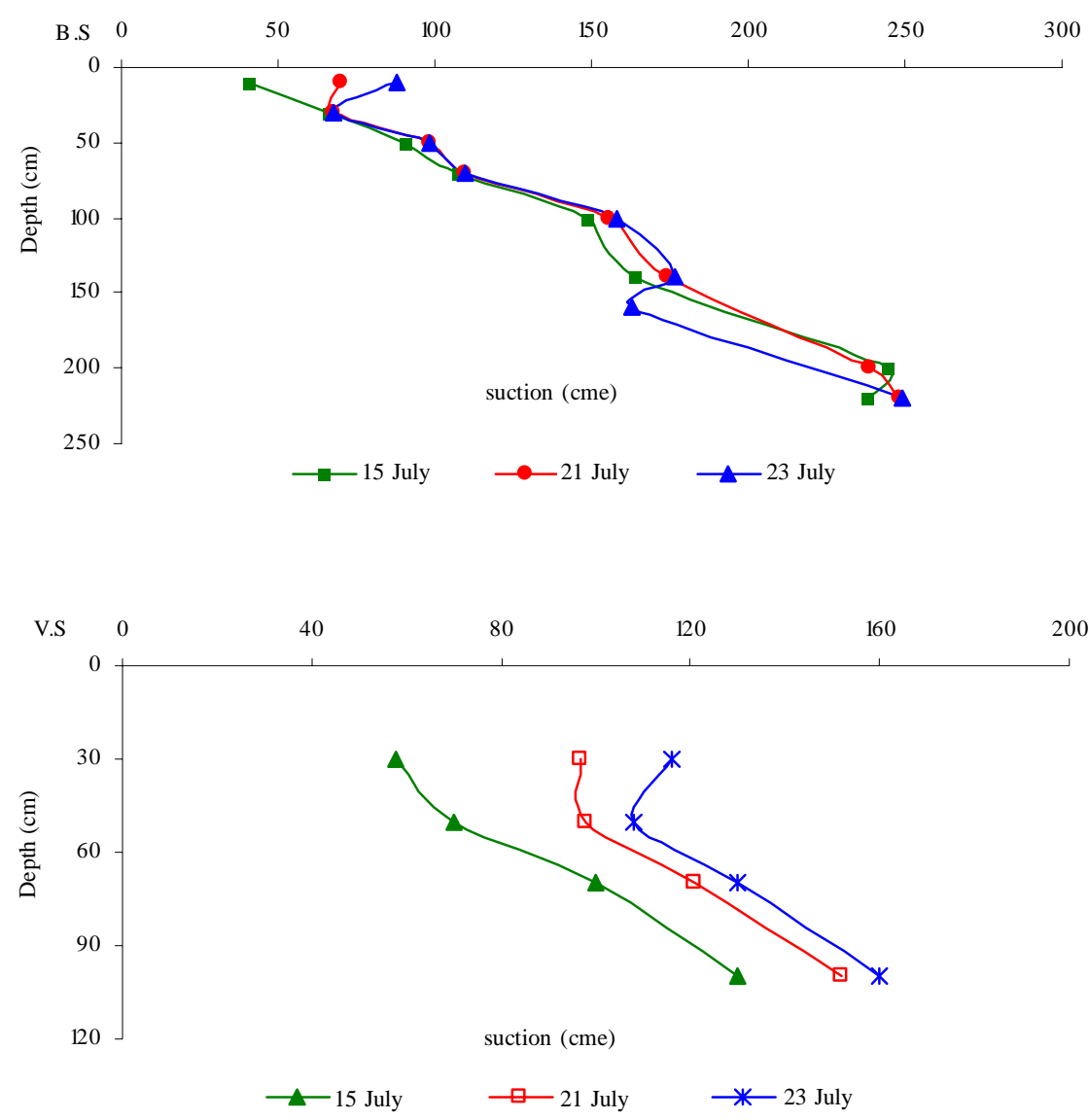

Fig. 7: Tensiometric profiles (15, 21 and 23 July 2006). The profiles (B.S and V.S) show a continuous draining of moisture within the soil with depth

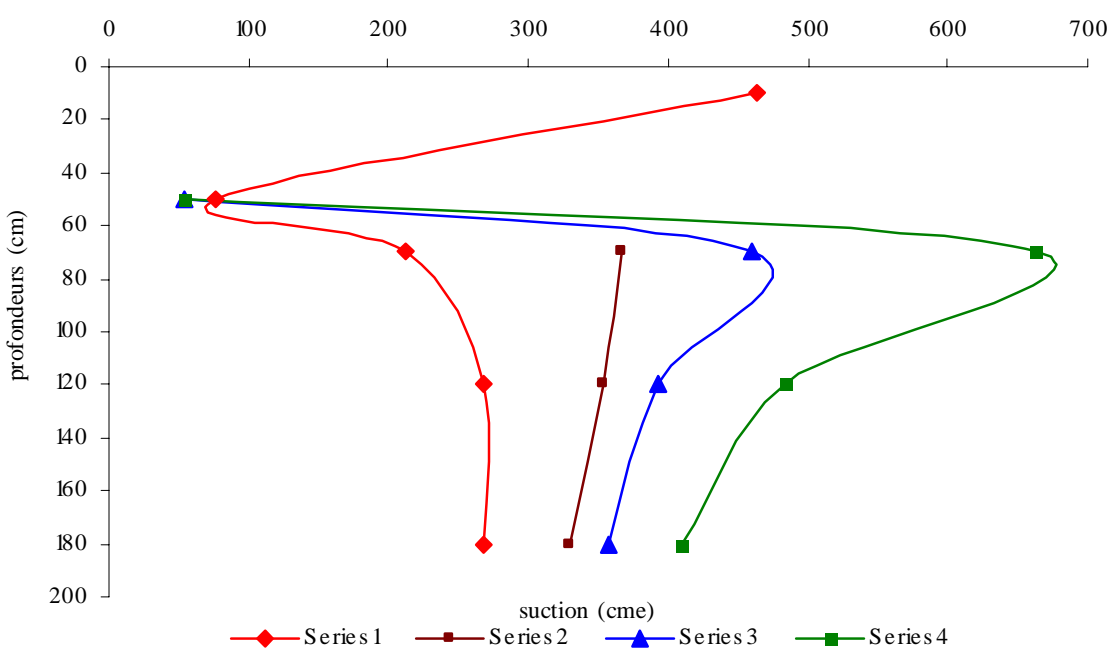

Fig. 8: Tensiometric profiles before rainfall (2, 19 and 23 August) and after rainfall (2 September). This figure illustrates the influence of rainfall on the soil suction value 
surface and a gradual decrease with depth. A more detailed study of these variations at identical depths showed that the moisture content in vegetative site have always been at higher level than those in barren site at depth up to $180 \mathrm{~cm}$. These are in conformity with the neutron moisture probe results and confirm that these two methods (tensiometric and neutronic) are adequate for taking moisture measurements. The influence of rainfall was very significant on vegetative site profiles (Fig. 8). The rains received before the last transactions were recorded on July 26 and August 23. This means that the profiles of August 2 and 19 took place during dry period. It was observed that the soil was very dry at the surface and slightly at lower depth on August 2. The drying up of layers of subsurface however continued over time. It was also observed with rainfall on August 23 and September 2 that there was switching of profiles on the surface, but a continuous and gradual drying at lower depth. This meant that the moisture front had not yet reached the layers at lower depth. There was a delay in moisture or drying on the two sites and the delay was more significant as the series of previous rainfall events were more distant .

\section{CONCLUSION}

Measurement of moisture content using moisture probe in the soils at the test site were accurately estimated using noninvasive method. The application of neutron thermalization in the study shows excellent promise for monitoring spatial and temporal variability in moisture content in a soil profile. The results indicated that the spatial distribution of profiles was influenced by vegetative cover and soil type. Although the surface moisture content was generally low, it has been noted a gradual increase in moisture content up to $110 \mathrm{~cm}$ depth in the both sites. The suction values were relatively strong in surface, strong in the intermediate layers and weak at depth. Although suctions were varied and moisture content different from one site to another, it was found that the soils of forest areas were quite wet and retained the moisture up to certain depth with time, particularly to the sites deprived of vegetation. However, it is suggested that the investigation depth of the study must be expanded to assess the possibility of measuring ground water recharge at depth where ground water is present.

\section{REFERENCES}

Boeglin, J. L.; Ndam, J. R.; Braun, J. J., (2003). Composition of the different reservoir waters in a tropical humid area: Example of the Nsimi catchment (Southern Cameroon). J. Afr. Earth Sci., 37 (1-2), 103-110 (8 pages).

Braun, J. J.; Bedimo Bedimo, J. P.; Robain, H.; Ndam, J. R.; Viers, J.; Dupre, B.; Olivier-Laquet, G.; Yene Atangana, Q.; Takeu, A., (1998). Fonctionnement des écosystèmes tropicaux humides: Influence sur les ressources hydriques et la qualité des eaux. Exemple du bassin fluvial du Nyong (SudCameroun). Géosciences au Cameroun, Vicat J. M.; Bilong P. (Eds.). Collection Geocam, 1/1998, 23-40.

Braun, J. J.; Ndam, N. J. R.; Viers, J.; Dupré, B.; Bedimo, J. P.; Boeglin, J. L.; Robain, H.; Nyeck, B.; Freydier, R.; Sigha, N. L.; Rouiller, J.; Muller, J. P., (2005). Present weathering rates in humid tropical watershed: Nsimi, South Cameroon. Geochim. Cosmochim. Ac., 69 (2) 357-387 (31 pages).

Braun, J. J.; Viers, J.; Dupre, B.; Polve, M.; Ndam, J.; Muller, J. P., (1997). Solid/liquid REE fractionation in the lateritic system of Goyoum, East Cameroon: The implication for the present dynamics of the soil covers of the humid tropical regions. Geochim. Cosmochim. Ac., 62 (2) 273-299 (27 pages).

Dalton, F. N., (1992). Development of time-domain reflectometry for measuring soil water content and bulk soil electrical conductivity. Topp, G. C.; Reynolds, W. D.; Green, R. E. Eds., Advances in measurement of soil physical properties: Bringing theory into practice, Soil Science Soc. Am., Madison, Wisconsin, 30, 143-167.

Evett, S. R., (2003). Soil water measurement by neutron thermalization. Steward and Terry Howell editors. USDAARS, Texas, USA, 78-91.

Evett, S. R., (2004). Profile water content measurement for soil water balance: Systems compared. Agronomy abstracts, ASA-CSSA-SSSA, Annual meeting, Seattle, Washington. USA.

Evett, S. R.; Steiner, J. L., (1995). Precision of neutron scattering and capacitance type soil water content gauges from field calibration. Soil Sci. Soc. Am. J., 59 (4) 961-968 (8 pages).

Falleiros, M. C.; Ravelo, A. S.; Dormelas de Souza, M.; Bacchi, O. O. S.; Pilotto, J. E.; Reichardt, K., (1993). Neutron probe measurement of soil water content close to soil surface. Sci. Agri. (Piracicaba, Brazil), 50 (3), 333-337 (5 pages).

Fares, A. P.; Dalton, M.; El-Kadi, A. I.; Parsons, L. R., (2004). Dual field calibration of capacitance and neutron soil water sensors in a shrinking-swelling clay soil. Soil Science Society of America, Vadose Zone J., 3, 1390-1399 (10 pages).

Fih, M. A., (1999). Transferts hydriques au sein des couvertures d'altération latéritiques des écosystèmes tropicaux forestiers humides. Cas du B.V. E. de Nsimi, Sud-Cameroun. M.Sc. thesis, University of Dschang, Cameroon, 86.

Healey, R. W.; Cook, P. G., (2002). Using groundwater levels to estimate recharge. Hydrogeol. J., 10 (1), 91-109 (19 pages).

Kuitcha, D., (2002). Hydrodynamique comparée des sols en forêts et en savane arbustive: Exemple des bassins du Mengong à Nsimi et de Ngoua à Dschang. Mémoire DEA. Université de Yaoundé I, Cameroun, 75.

Lasserre, M.; Soba, D., (1979). Migmatisation d’âge panafricain au sein des formations Camerounaises appartenant à la zone mobile de l'Afrique Centrale. Bul. Soc. Géol. de France, 64-68 (5 pages). 
Maréchal, J. C.; Riotte, J.; Braun, J. J.; Ruiz, L.; Kumar, M.; Varma, M.; Sekhar, M.; Ndam Ngoupayou, J.; Lagane, C., (2008). Chemical groundwater outputs from small drainage basins: Two tropical examples. Geophys. Res. Abstracts, Vol. 10, EGU2008-A-12419, SRef-ID: 1607-7962/gra/ EGU2008-A-12419.

Ndam, J. R., (1997). Bilans hydrogéochimiques sous forêt tropicale humide en Afrique du bassin expérimental de Nsimizoétélé aux réseaux hydrographiques du Nyong et de la sanaga au Sud-Cameroun. Th. Doc., Univ. Pierre et Marie Curie, Paris, VI. 213.

Norman, L. K.; Gary, W. H., (1990). How soil holds water. Institute of Agriculture and Natural resources. University of Nebraska-Lincoln, USA., 263.

Olivry, J. C.; Sircoulon, J., (1998). Developing hydrology research in partnership in sub-Saharan Africa: The example of the french-speaking countries. Rev. Sci. eau., special issue, 61-75 (15 pages).

Pourrut, P.; Camus, H., (1970). Etude fine du bilan hydrique par utilisation de la sonde à neutrons. In Results of research in representative and experimental basins. Aish-Unesco: 1, 708-737.

Reedy, R. C.; Scanlon, B. R., (2003). Soil water content and water storage monitoring using electromagnetic induction. J. Geotech. Geoenviron., 129 (11), 1028-1039 (12 pages).

Reichardt, K.; Portezan, O.; Bacchi, O. O. S.; Oliveira, J. C. M.; Douradoneto, D.; Pilotto, J. E.; Calcache, M., (1997). Neutron probe calibration correction by temporal stability parameters of soil water content probability distribution. Sci. Agri. (Piracicaba, Brazil.), 54 (special issue), 17-21 (5 pages).

Sekhar, M.; Braun, J. J.; Hayagreera Rao, K. V.; Ruiz, L.; Robain, H.; Viers, J.; Ndam, J. R.; Dupre, B., (2007). Hydrogeochemical modeling of organo-metallic colloids in the Nsimi experimental watershed, South Cameroon. Environ. Geol., 54 (4), 831-841 (11 pages).

Temgoua, E.; Djeuda Tchapnga, H. B.; Tanawa, E.; Guenat, C.; Pfeifer, H. R., (2005). Groundwater fluctuations and footslope ferricrete soils in the humid tropical zone of Southern Cameroon. Hydrol. Proc., 19 (16) 3097-3111 (15 pages).

Thais, P. A., (2004). Etude du transfert d'eau et de solutés dans un sol à nappe superficielle drainée artificiellement. Thèse doc. Ecole Nationale du Génie Rural, des Eaux et Forêts, Paris, France, 188.

Tienjo, K. C., (2007). Use of Porchet method in view of the study of the modalities of aquifer recharge of the soils in the watershed of Nsimi. M.Sc. thesis, Univ. Yaoundé I, Cameroon. 67.

Toteu, S. F.; Van Schmu, W. R.; Penaye, J.; Michard, A., (2001). New U-Pb and Sm-Nd data from north-central Cameroon and its bearing on the pre-Pan African history of central Africa. Precamb. Res. 108 (1-2) , $45-73$ (29 pages).

Vicente, M. A.; Gallardo, J. F.; Gerardo, M.; Gonzalez, M. I., (2003). Comparison of soil water-contents as measured with a neutron probe and time domain reflectometry in a mediterranean forest ("Sierra de Gata", Central Western Spain). Ann. For. Sci., 60, 185-193 (9 pages).

Viers, J.; Dupre, B.; Polve, M.; Schott, J.; Dandurand, J. L.; Braun, J. J., (1997). Chemical weathering in the drainage basin of a tropical watershed (Nsimi-Zoetele site, Cameroon) comparison between organic-poor and organic-rich waters. Chem. Geol., 140 (3-4), 181-206 (26 pages).

Yene Atangana, J. Q.; Nyeck, B.; Bitom, D.; Robain, H., (2003). Self potential anomalities in the lateritics cover of the Nsimi watershed in Southern Cameroon: Origin and influence of electrical and granulometric parameters. J. Appl. Geophys., 54 (1-2), 85-96 (12 pages).

\section{AUTHOR (S) BIOSKETCHES}

Fouépé, T. A., M.Sc., Researcher at the Institute for Geological and Mining Research, and a Ph.D. student at the Department of Earth Sciences, University of Yaounde I, Yaounde, Cameroon. Email: afouepe@yahoo.fr

Kengni, L., Ph.D., Lecturer at the Department of Earth Sciences, University of Dschang, Dschang, Cameroon. Email: lkengni@yahoo.fr

Gurunadha Rao, V. V. S., Ph.D., Scientist G, Deputy Director and Head of the Ecology and Environment Group at the National Geophysical Research Institute of Hyderabad, Hyderabad, India. Email: gurunadharaovvs@gmail.com

Ndam, N. J. R., Ph.D., Lecturer at the Department of Earth Sciences, University of Yaounde I. Yaounde, Cameroon. Email:jrndam@yahoo.fr

This article should be referenced as follows:

Fouépé T. A.; Kengni L.; Gurunadha Rao V. V. S.; Ndam N. J.R., (2009). Transfer of moisture through the unsaturated zone in the tropical forest using the neutron probe. Int. J. Environ. Sci. Tech., 6 (3), 379-388. 